\title{
Is the Electronic Recruitment In Algeria : The Alternative or Complement to the Regular Conscription?
}

\author{
Tafiani Born Boufatah Keltouma \\ Faculty of Economic Sciences, University Abu Bakr Bilkaid \\ Tlemcen, Algeria \\ Email: boufatehkeltouma [AT] gmail.com
}

\begin{abstract}
This study aims to find out whether the internet approach can achieve a high percentage of equality and provide rational job quality. According to some studies, or can say that by following this approach (the internet), the inequality of recruitment can be reduced proportionally by facilitating meetings, interviews, contacts and exchanges. Algeria is among the countries most thirsty for qualifications and fairness in recruitment, for this reason our human resources management specialists find that the use of websites and social networks can alleviate some problems.
\end{abstract}

Keywords--- recruitment ,electronic recruitment, internet, Algerians enterprises, professional networks

\section{INTRODUCTION}

After the Internet has become an essential gateway in all levels of life, all the most diverse geographical borders have melted away, especially when it comes to human talent and professional mobilization by increasing the demand for it in a world full of thriving digital economies so that this is the ideal place for this electronic medium that may be the decisive Finding a permanent job, or earning permissible, through which the job seeker can improve his life financially, by virtue of the fact that the electronic process consumes less time in making the appointment decision, reducing the cost of recruitment, and reaching the largest number of business owners, in contrast to the traditional methods of employment that are often restricted in degree Functionalism, geography and other criteria.

On the websites there are many requests and registrations, as the latter is now working to sensitize the concerned by the inclusion of job applications directly on the Internet, and in return it has started an awareness process with institutions and job seekers in order to move from registration

From traditional registration to electronic, as it guarantees effectiveness and transparency, and guarantees the best competencies in various disciplines in a short period.

In a very dynamic world, Algerian institutions are finding it increasingly difficult to pursue an effective employment policy to attract and select young graduates, however the latter has many methods, among which is the electronic approach to recruitment, where the use of information and communication technology, including social networks.

The problem at hand is:

Can the internet approach achieve the principle of equality in various fields, including the management of human resources, especially recruitment or employment?

Therefore, we put the following hypotheses:

-This approach can facilitate meetings, interviews, contacts and exchanges for more equitable recruitment.

- By following the l'internet approach, inequality in recruitment can be alleviated.

- The Internet works to bring about high quality employment.

In order to address this problem, we followed the following plan:

First: the definition of electronic employment.

Second: The history of electronic employment.

Third: Electronic employment in Algeria.

In this context, we touched upon the main sites used for recruitment in Algeria and the most well-known professionnels job networks in Algeria.

And to what extent was the use of these functional networks in Algerian institutions. What are the most important problems affecting the quality of electronic recruitment in Algeria? Finally, what are the challenges and issues that Algerian institutions face in the field of recruitment? 


\section{DEFINITION OF ELECTRONIC EMPLOYMENT}

This term lacked an accurate definition due to its novelty. That is why the specialists in the management of human resources agreed that electronic recruitment, also called "online recruitment" is the process of recruiting potential candidates to fill vacancies, using electronic resources, especially the Internet.

Electronic recruitment is nothing but the removal of the dématérialisation of the materialistic relationship that exists between the user and the user, it means determining the origin of the recruitment process on the Internet, such as using a rich use ground in terms of CV.

It includes the entire process of finding, evaluating, interviewing and recruiting potential candidates according to the job requirements, through this method the recruitment is done more effectively and efficiently. Generally, vacancies are advertised on the Internet; The companies carry out their promotional activities and the candidate can decide whether he is part of the company or not.

Electronic recruitment is nothing but a modern and digital translation of some of the stages of traditional employment.

II. Date of employment or the origin of electronic employment:

The latter went through stages, the most important of which are:

\section{Web 1.0 WEB1.0}

The user is the one who goes to search for information with a single reading, because the exchange and distribution was not possible.

\section{2- E-Employment 2.0 Social Space:}

The World Wide Web relatively changed recruitment patterns until the mid-2000s, converting paper ads into web ads and resumes into distributable electronic files.

With the advent of WEB2.04 and with the advent of social networks, the Foundation now manages the recruitment of candidates, by means of for example FACEBOOK; viadeo. LinkedIn Twitter and videos.

The two sides are concerned in this case with the candidate to develop his network, and the second is to activate the user brand or the professions' specializations.

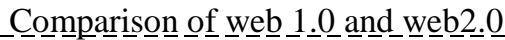

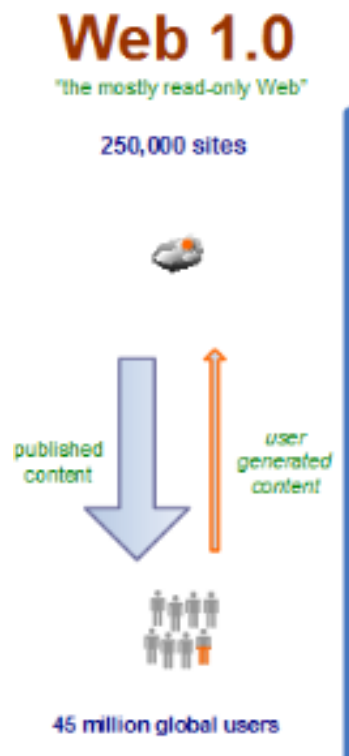

1996

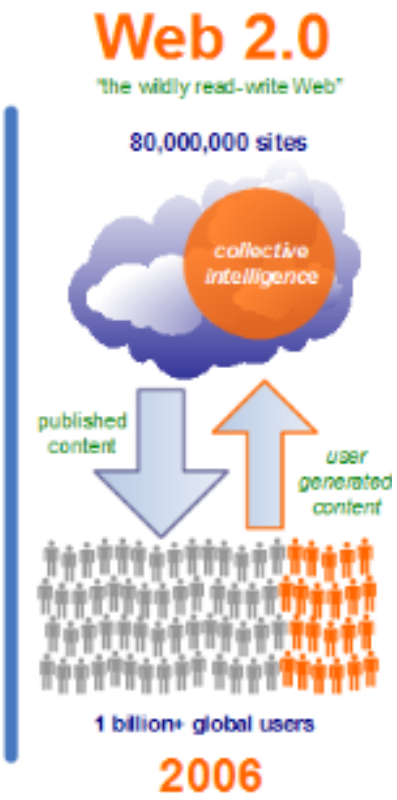

2006

Source: Umesha Naik Comparative Study of Web1.0‘ Web2.0، Web3.0 19August 42014

\section{Recruitment 3.0l'inboundrecrutment}

The principle is to spread the important informational and diverse messages (photos, videos, articles, newsletters ...) to potential competencies in order to strengthen the image and credibility of the institution.

Comparison of web 1.0, web2.0, and web3.0 


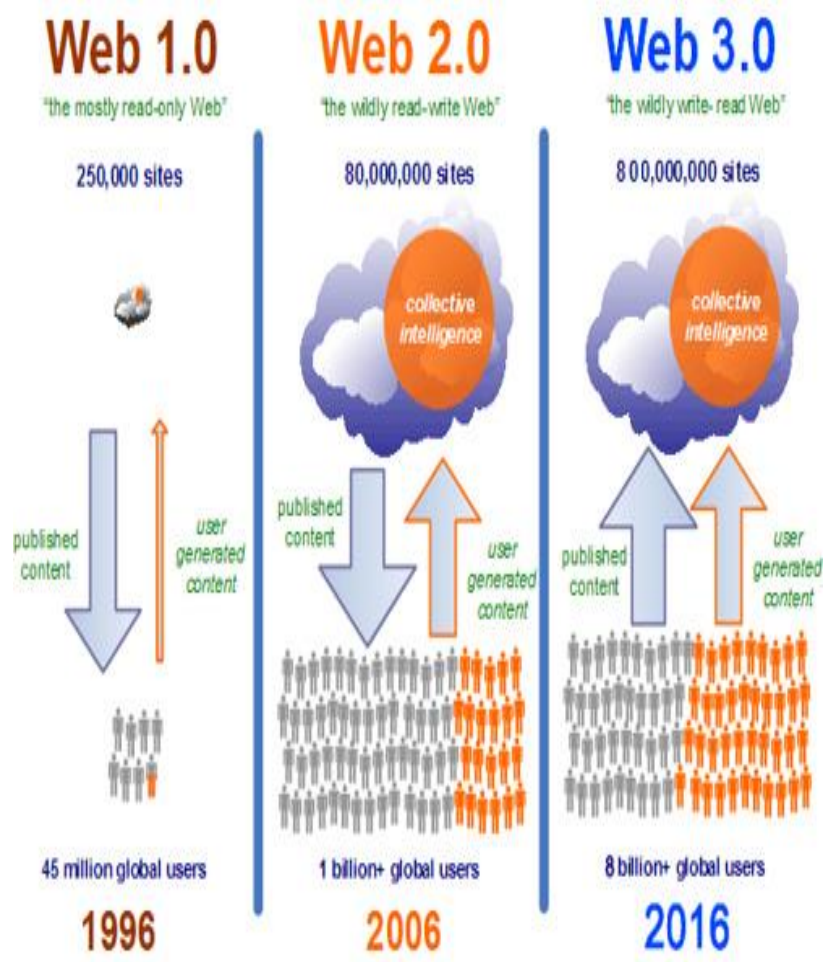

Umesha Naik Comparative Study of Web1.0، Web2.0، Web3.0 19August 42014

\begin{tabular}{|c|c|c|c|}
\hline & web1.0 & 2.0 web & Web 3.0 \\
\hline 1 & 1996 & 2006 & 2016 \\
\hline 2 & web & web social & Semantic Web \\
\hline 3 & Web reading only & Read and write web & $\begin{array}{l}\text { Reading, writing and stating } \\
\text { the web }\end{array}$ \\
\hline 4 & Share information & Interaction & immersion \\
\hline 5 & One million users & One billion users & One trillion users \\
\hline 6 & environmental system & Share & Understand himself \\
\hline 7 & Linking information & Connecting people & Connect knowledge \\
\hline 8 & Brain and eyes information & $\begin{array}{l}\text { Brain, eye, sound, heart, any } \\
\text { emotion }\end{array}$ & $\begin{array}{l}\text { Brain, eye, ears, sound, heart, } \\
\text { arms, legs, freedom }\end{array}$ \\
\hline 9 & Hypertext & $\begin{array}{l}\text { Web community, applications, } \\
\text { sites that link them }\end{array}$ & Semantic Web of Machines \\
\hline 10 & Internet, texts, graphics .... & Bidirectional web pages & $\begin{array}{l}\text { 3D Gateway is a multi-user } \\
\text { virtual environment }\end{array}$ \\
\hline 11 & $\begin{array}{l}\text { Companies are posting } \\
\text { content for people to } \\
\text { consume }\end{array}$ & $\begin{array}{l}\text { Posting content to the public and } \\
\text { creating platforms that allow } \\
\text { people to post content to other } \\
\text { people }\end{array}$ & $\begin{array}{l}\text { People build applications that } \\
\text { interact with others with } \\
\text { forms, create platforms to } \\
\text { publish services, and leverage } \\
\text { connections }\end{array}$ \\
\hline 12 & $\begin{array}{l}\text { In web } 0.1 \text {, search engines } \\
\text { retrieve the contents. The } \\
\text { search is very fast, but often } \\
\text { the results are inaccurate }\end{array}$ & $\begin{array}{l}\text { In web 2.0, search engines } \\
\text { retrieve tags with micro wi } \\
\text { content }\end{array}$ & $\begin{array}{l}\text { In Web } 0.3 \text {, search engines } \\
\text { automatically retrieve the } \\
\text { texts of the encyclopedia's } \\
\text { small content }\end{array}$ \\
\hline 13 & $\begin{array}{l}\text { web } 1.0 \text { relates to static } \\
\text { content without interaction } \\
\text { between readers or } \\
\text { publishers }\end{array}$ & $\begin{array}{l}\text { web } 0.2 \text { is bidirectional } \\
\text { communication }\end{array}$ & $\begin{array}{l}\text { Web } \quad 0.3 \quad \text { Artificial } \\
\text { Intelligence }\end{array}$ \\
\hline 14 & $\begin{array}{l}\text { The first development of the } \\
\text { web was Web } 1.0\end{array}$ & $\begin{array}{l}\text { The developments allow for user } \\
\text { interaction with web pages, } \\
\text { citizen journalism and social } \\
\text { networks }\end{array}$ & $\begin{array}{l}\text { Developments that allow } \\
\text { interaction and lead to } \\
\text { artificial intelligence }\end{array}$ \\
\hline
\end{tabular}




\begin{tabular}{|r|l|l|l|}
\hline 15 & Personal web sites & Blogging & Semantic Blogging \\
\hline 16 & $\begin{array}{l}\text { Content management } \\
\text { system, }\end{array}$ & Book portals, Wikipedia & Semantic Wikipedia \\
\hline 17 & Google AltaVista & Google Search Diagnostic & Semantic search \\
\hline 18 & Project Gutenberg & Comgle Books Search & Digital Semantic Libraries \\
\hline 19 & Message boards & $\begin{array}{l}\text { Semantic forums and } \\
\text { community portals }\end{array}$ & Semantic social networks \\
\hline 21 & $\begin{array}{l}\text { En savoir plus sur ce texte } \\
\text { sourceVous devez indiquer } \\
\text { le texte source pour obtenir } \\
\text { des informations } \\
\text { supplémentaires }\end{array}$ & $\begin{array}{l}\text { En savoir plus sur ce texte } \\
\text { sourceVous devez indiquer le } \\
\text { informations source pour obtenir des } \\
\text { information }\end{array}$ & $\begin{array}{l}\text { Semantic social informentaires } \\
\text { spaces }\end{array}$ \\
\hline
\end{tabular}

\section{4-. Recruitment 4.0}

The candidate and the user both want to stand out. The candidate works on confronting his competitors from among the candidates, and the corporation is working on facing its competitors from other institutions.

\section{5- Artificial intelligence}

It is used more and more for the analysis of CVs and motivation messages, from the initial testing procedure of the candidates.

Emmanuel vivier (InstituteHUB) proposes every day to pick out trends and the best technological innovations. For example: casque de projection spéciale traduisant les sensations vécues dans un scaphandre. Written by HUB Institute, posted on 29-03-2018.

\section{6- Recruitment through a robot: a robot in South Korea:}

The future of electronic recruitment is in its mechanism. Some organizations develop automated interviews where the candidate faces the screen and answers the questions posed to him. The response elements, the strength of the voice, as well as the facial expressions disintegrate. This method allows you to gain time and reduce discrimination in hiring.

\section{The social loan system: le social crédit system :}

It is the answer to the following question: How much a citizen is socially worth or what is a citizen's social value. We imagine that a society where our activity and our interaction with each other is positive and negative, as the sum of these evaluations gives us a general point called Score citoyen. The goal is to develop is to develop a sense of confidence and build a culture of sincérité.

This system is considered unnecessary today, but it will become mandatory in China from 2020.

\section{INTEGRATION OF THE SOCIAL NETWORK INTO THE INSTITUTION'S STRATEGY:}

The unidentified social network complexes are mainly used by recruitment experts and their mission is to provide a single point of access on the Internet by aggregating the content of multiple social networks on one site. Hence, it is a tool capable of gathering and synthesizing data and content in real time that is distributed over multiple sites. It provides a central view of what is happening at the same time on all of the networks we belong to. Their presence responds to the basic need of employers, i.e. organizations, and it saves time to ensure their online presence takes a long time. The most famous ones are FriendFeed and Seesmic 
The following table shows the company's developments across the web

Source:réseauxsociaux dans une stratégie d'entreprise (2010) page 200

C.Balague. D.Fayon Facebook. Twitter et les autre... intégrer les

\begin{tabular}{|l|l|l|}
\hline \multicolumn{1}{|c|}{ a company3.0 } & \multicolumn{1}{|c|}{ a company2.0 } & \multicolumn{1}{|c|}{ a company 1.0 } \\
\hline $\begin{array}{l}\text { Horizontal and scaled organization } \\
\text { with crowdsourcing }\end{array}$ & Horizontal organization & $\begin{array}{l}\text { Hierarchical } \\
\text { organization }\end{array}$ \\
\hline $\begin{array}{l}\text { Participation with the development } \\
\text { of all forms of remote work }\end{array}$ & Share & Partition \\
\hline $\begin{array}{l}\text { Flexible and intelligently optimized } \\
\text { simple procedures }\end{array}$ & $\begin{array}{l}\text { Simple and flexible } \\
\text { procedures }\end{array}$ & $\begin{array}{l}\text { Complex procedures } \\
\text { and rigidity }\end{array}$ \\
\hline $\begin{array}{l}\text { The relationship between everyone } \\
\text { and at all times }\end{array}$ & $\begin{array}{l}\text { The relationship between } \\
\text { everyone }\end{array}$ & $\begin{array}{l}\text { Hierarchical } \\
\text { relationship }\end{array}$ \\
\hline $\begin{array}{l}\text { The information is shared and } \\
\text { qualified according to its meaning }\end{array}$ & Common information & Information saved \\
\hline $\begin{array}{l}\text { Corporate social networks 3D } \\
\text { virtual universes }\end{array}$ & $\begin{array}{l}\text { Kinds of social } \\
\text { networking tools for the } \\
\text { company }\end{array}$ & $\begin{array}{l}\text { Web1.0 Tools: Email } \\
\text { Enterprise Website ... }\end{array}$ \\
\hline $\begin{array}{l}\text { E-learning on demand for specific } \\
\text { points thanks to data rehabilitation }\end{array}$ & E-Learning & $\begin{array}{l}\text { Classic face-to-face } \\
\text { training }\end{array}$ \\
\hline
\end{tabular}

Through the table, it is clear to us that the characteristics conveyed by modern technologies modify the organization of companies that become horizontal and human relations less hierarchical. Here, the recruiter must know the consequences of these developments that may lead to a new "relational dynamic".

\section{ONLINE EMPLOYMENT IN ALGERIA}

The importance of online recruitment in Algeria appears to:

-It contributes to the acceleration of the work process, and allows the selection of the qualified workforce and the competencies needed by any institution in a standard circumstance, especially since the tremendous technological development and the spread of websites and employment pages through social networks and the Internet push the need to keep pace with the situation.

Electronic recruitment guarantees effective mediation in a short time. E-employment, whether for job seekers or in the field of job offers, is an outstanding experience despite its youth, as it contributes to achieving mediation in the field of work at the lowest costs, in an effective manner and in record time.

- It became clear from the activation of the electronic registration of the exhibitors and job seekers, that there was a sense of facilitating the quality of services and overcoming the obstacles that were facing in order to achieve mediation, as well as eliminating the queuing problem that had long accompanied the various "Anam" offices, and at the same time alleviated the burden of periodic movement towards agencies Employment for job seekers, especially in the Greater South, so the modern technology saves effort, money and time.

With regard to preparing lists of candidates for the positions offered, it has become easy to prepare and automated, as agencies contact by phone informing each candidate by e-mail, thus avoiding the hassle of moving to the agency's offices, and at the same time it has become possible for job seekers to renew the registration document in the agency electronically .

\section{THE MAIN SITES FOR ONLINE EMPLOYMENT IN ALGERIA}

-empoitic.com: it is djeezy's choice partner; Arab Bankcorporation; société alliance assurances -oued kniss: Using this site to accept legislation or a rule stipulating respect for the personal life of candidates.

\section{THE MOST FAMOUS PROFESSIONAL NETWORKS IN ALGERIA}

- Linkedin-: It is most used globally.

- via deo-: It's the least used if you compare it to LinkedIn.

- face book: Users 2.0 gives great importance to this online network.

- Twitter: With just key words such as position name and location with multiple relationships and the insertion of what is known as hashtags, electronic recruitment can be done. 


\section{THE MOST IMPORTANT INSTITUTIONS USING SOCIAL NETWORKS IN ALGERIA}

Social networks are considered very recent in Algeria. These institutions can be classified into three categories: In the first, we find those that are actively involved in competitive activities such as: telephones and cars. In the second place: the small trade sector, for example restaurants and craftsmen.

The question is: Are social networks used in non-lucratif non-profit organizations?

Personal preparation depending on the webdialna website

\section{SOME STATISTICS ABOUT THE DEVELOPMENT OF INTERNET USE IN ALGERIA}

Online statistics results achieved in October 2012 by webdialna state that:

At least $66 \%$ of job advertisements were published online, compared to $34 \%$ in written newspapers.

- According to a 2012 report on a web in Algeria published by emploitic.com, the pioneer of online recruitment: a total of 15,000 job advertisements published through the most important media outlets such as the press and the web.

We notice a very noticeable development in the deployment of employment positions on the web. The following table illustrates this:

\begin{tabular}{|r|r|}
\hline web Advertisement & years \\
\hline Of the total ads $20 \%$ & 2009 \\
\hline Of the total ads $40 \%$ & 2010 \\
\hline Of the total ads $60 \%$ & 2011 \\
\hline
\end{tabular}

Personal preparation based on data webdialna

\section{THE REALITY OF ONLINE EMPLOYMENT IN ALGERIA}

The digital presence in the world of work in Algeria has gradually become effective in the search for vacant jobs, and companies, institutions and even government departments are looking to attract human competencies in the electronic job search system by submitting job applications automatically without the need to personally come to the announced institutions where no less than 66 have been published. According to emploitic.com, according to emploitic.com, only $43 \%$ of recorded job advertisements registered on the Internet compared to only $43 \%$ in the written press.

\section{THE MOST IMPORTANT PROBLEMS AFFECTING THE QUALITY OF ONLINE RECRUITMENT IN ALGERIA}

The problem is how the job is displayed to the user and the $\mathrm{cv}$ is displayed to the user Years of development in the use of the Internet

\begin{tabular}{|l|l|}
\hline 2010 & $12 \%$ \\
\hline 2011 & $18 \%$ \\
\hline 2012 & $27 \%$ \\
\hline
\end{tabular}

Offering the job without tempting the candidate (the brand of the institution, regardless of its type, in terms of balance between personal and professional life, working hours, the most important job tasks, the possibility of continuous training, its type, etc.). The Algerian institution does not need to clarify the brand because there is a significant need for the job, whatever it is ( Growing unemployment, especially positions for undergraduates, long-term education.)

- Most of the time, some of the competencies in specific positions, or rather in specific specializations, are recruited in a field other than that, even if they use the Internet for their recruitment.

The mentalities of the individuals managing human resources are still entrenched in Algerian institutions and this is evident in the old practices as the electronic network has not reached the point of alleviating the dilemma of discrimination during recruitment despite the publication of advertisements on the Internet (the problem of time remains, and deficiencies in information directed at the public).

There is a big gap between what is published and what is achieved.

Employment via the internet and social media is limited in time and is linked to contracts, which leads to the separation of work from social security networks such as health insurance or pensions.

The bad use of bringing job opportunities electronically necessitates organizing training courses so that young people can enter the world of digital work comfortably and without consequences. 
- The legal consequences are the result of the wrong use of getting a job through websites or social media pages, as information technology is a challenge for workers and employers. Where the sector is still closed in itself.

On the other hand, more formal career paths can be drawn, as well as they will develop the concept of our national economy and make the state an alternative to the oil wealth, which created a global crisis that the government realized late.

- To avoid the possibilities of forgery and the preparation of documents and testimonies, it is necessary to subject each file to scrutiny before deciding on the issue of employing it or not, given that the virtual judiciary is not subject to real control, as any job applicant can declare data and features that are not available in it, so the verification process must be approved in all Files that access the Enterprise Manager.

\section{THE MOST IMPORTANT CHALLENGES FACED BY ALGERIAN ENTERPRISES IN THE FIELD OF ELECTRONIC EMPLOYMENT}

The Algerian economy is oriented to services. In order to create value, the business focuses on human resources. Intellectual competencies are at stake. Engineer, economist, law degree holders, finance professionals, information and communication technology specialists ...

Filled heads are the most in demand in the future. In order to continue to progress and face this situation, Algerian institutions must permanently register in the battle of competencies. It must adapt in order to bring in and support young talents through the transformation digitale stages that must go through.

How can human resources meet this challenge:

First we must reach the goal that the best candidates are the ones concerned with the clothes of l'embarras du choix.

Secondly, the ambition is to reach the brand of the used institution as the main factor in attracting competencies (flexibility in organizing work, for example, adapted times, the best balance between professional and private life, growing independence and transparency, and prospects for development through continuous training).

And the scales of that, human resources must advance in understanding the channels of communication, especially the Internet sites and social networks that are most popular among young candidates. This leads to improvement in the activity and quality of recruitment or hiring.

The other question that arises is how to accept all these cases

Broadly, the HR function has to become electronic, and those responsible for these resources and recruiting can focus on the tasks that bring the strongest added value, such as developing the user's brand and making the organization more flexible in its organization.

\section{PROSPECTS FOR ONLINE EMPLOYMENT IN ALGERIA}

The regional symposium on the contribution of the digital economy to the growth of the countries of North Africa and the Middle East highlighted the need for the national economy to move towards an economy based on digitism as it relies on information and software technologies in the field of job creation, especially for young people, while their dream of finding a permanent job that will provide them with Several facilities in their social life. Wherever Algeria remains at the bottom of the world ranking in electronic services, it ranked 150th in the world. But the entry of our national economy into the world of digitization will create a new dynamic to provide job opportunities from behind computer screens under the slogan of the computer economy or the mental economy, which replaces the economy of work, land and machine as a source of wealth, according to what Yunus said, similar to the expert in media and communication technology for Al Shorouk Economy.

The rapid development of information technology contributes to enhancing the ability of industrial enterprises to innovate, which is a fundamental factor of production, just as capital and labor are, but is considered the most important of them because it is the main engine and catalyst for qualitative growth affecting the world of employment andAnd search for vacancies.

One of the most important measures to encourage electronic employment in Algeria, reduce unemployment and underemployment, as well as raise the level of job satisfaction electronically, is the creation of an electronic platform for the job market to attract qualified human resources. Although these platforms are unable to boost weak demand, solve complex development issues in the emerging world of work, or create better job opportunities in various sectors, they are able to leave a significant footprint on our digital economy. Therefore, it has become necessary to develop electronic platforms for work, and this step requires a special training for job seekers and announced institutions, and this will contribute to the development of our digital economy, and make it open to all public and private sectors, so that there is a new electronic panorama in the world of work.

\section{RESULTS}

With the advancement and development of information technologies and means of communication and the connection of most if we do not transfer all our activities to the Internet, it has become necessary and inevitable that the methods of our 
search for work or the resurrection and creation of jobs in the era of modern technologies and what is expressed in the era of technology 3.0, which refer to a group of new technologies And the network applications that lead to changing the behavior of the World Wide Web. Employment via the Internet is economical, but you must be careful.

The exploitation of modern technologies in the field of employment is a double-edged sword, while it has positive aspects, it has negative aspects that must be taken care and caution not to fall into, that employment via the Internet is witnessing a remarkable development in Algeria, because of its effectiveness, rationality and accessibility On job applications in a comparative short period

With traditional employment, as well as being economical and inexpensive, it does not require large financial expenses, and it also paves the way for an unspecified number of requests in order to select the best competencies in various disciplines in a short period, which is what traditional employment sometimes fails to do.

Discrimination in employment, according to this modest study, diminishes with the use of electronic recruitment, and the specificity is multiplied, but the problem is when the individuals who are not used or are not enrolled in such networks are lacking, and the electronic recruitment and its facilitation for some stages does not mean dispensing with what is human, such as a personal interview.

Therefore, and in order to alleviate the problem at hand, some specialists believe that it is advisable to take into account the following options:

-Use the electronic recruitment with caution, because the digital and human means must work annually and in duplicate, according to what was stated by patricheleguide in one of his meetings. (22 fevrier 2017)(

-Among the risks of this type of employment: making mistakes, and it is from the parties to the candidate and the institution as a result of not providing correct and objective data.

Guaranteed marketing of the corporate brand in order to attract, recruit and retain the best talents and competencies

\section{CONCLUSION}

e-recruiting can generate a large amount of applications which seem to point out an advantage, but can also lead to a tedious and lengthy process. he was also criticized. Barber (2006) pointed out that loss of personal contact is a danger, and it is the type of job that determines whether or not e-recruiting is suitable.

So, companies should take these drawbacks into consideration when they plan and practice e-recruiting.

\section{REFERENCES}

1. -Charles-Henri Dumon recruter les meilleurs à l'ère digitale ; groupe eyrolles ; 2016

2. Laurent besson et jacques Digout e-recrutement à l'ère du Web 2.0 et des réseaux sociaux Vuibert; 01-092013

3. Emmanuel Vivier ; comment réussir une transformation digitale ; HUBInstitute 29-03-2018

4. BILL Fassino ; Chine : le système de crédit social ; comme une science-fiction dystopique; est en marche ; chroniqueur Actualités le21-09-2018

5. Webdialna Dossier de presse Etude sur les Usages et perceptions des internautes du Web Algérien. Octobre 2012.

6. F.Demarquet ; Autorité et management : quelles évolutions l'ère du numérique publié le 22-03-2017.

7. http://www.empoitic .com.

8-Fawzieh Masa'd Déploiement des médias sociaux dans le processus de recrutement, Février 2015

9-http://www.empoitic .com.

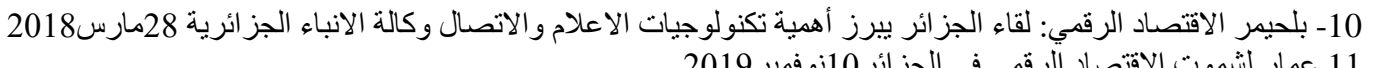$$
\text { 11.عمار لشموت الاقتصاد الرّقمي في الجزائر 10نوفير الجمبر } 2019
$$ 